\title{
Evaluation of Financial Condition and Performance Optimization of the Petrochemical Industry
}

\section{Organization in the Context of Increased Financial Risks}

\author{
Oksana Savchina $^{1, *}$, Aleksandr Bratanov ${ }^{2}$, Natalia Konovalova ${ }^{3}$, Svetlana Saksonova $^{4}$ \\ ${ }^{1}$ Department of Finance and Credit, Faculty of Economics, Peoples' Friendship University of Russia (RUDN University), Russian \\ Federation \\ ${ }^{2}$ Economics and Management Faculty, Moscow University of Industry and Finance "Synergy” (Synergy University), Russian \\ Federation \\ ${ }^{3}$ Economics and Finance Department, Faculty of Business and Economics, RISEBA University of Applied Sciences, Latvia \\ ${ }^{4}$ Finance and Accounting Department, Faculty of Business, Management and Economics, University of Latvia, Latvia
}

Received July 13, 2021; Revised September 15, 2021; Accepted September 29, 2021

\section{Cite This Paper in the following Citation Styles}

(a): [1] Oksana Savchina, Aleksandr Bratanov, Natalia Konovalova, Svetlana Saksonova, "Evaluation of Financial Condition and Performance Optimization of the Petrochemical Industry Organization in the Context of Increased Financial Risks," Universal Journal of Accounting and Finance, Vol. 9, No. 5, pp. 1169 - 1183, 2021. DOI: 10.13189/ujaf.2021.090526.

(b): Oksana Savchina, Aleksandr Bratanov, Natalia Konovalova, Svetlana Saksonova (2021). Evaluation of Financial Condition and Performance Optimization of the Petrochemical Industry Organization in the Context of Increased Financial Risks. Universal Journal of Accounting and Finance, 9(5), 1169 - 1183. DOI: 10.13189/ujaf.2021.090526.

Copyright $\bigcirc 2021$ by authors, all rights reserved. Authors agree that this article remains permanently open access under the terms of the Creative Commons Attribution License 4.0 International License

\begin{abstract}
The global petrochemical industry is one of the most dynamically developing - it is twice as fast as the world GDP in terms of growth rates. Over the past 20 years, significant changes have taken place in this industry. New major players have appeared and the structure has changed. As for Russia, its share in the global petrochemical production is about $2.5 \%$. At the same time, Russia is one of the world leaders in the production and export of hydrocarbon raw materials, where the country's share is about $12-19 \%$. Currently, a steady trend in the development of polymer materials science has been observed and it will continue to develop. In the next 15 years, the demand for petrochemical products will grow by an average of $4 \%$ per year. The purpose of this study is to analyze the financial standing, assess the prospects for development and optimize the activity of one of the largest systemically important organizations of the petrochemical industry in Russia - PJSC "SIBUR Holding" in the conditions of the macroeconomic instability. To implement the research the authors have collected financial data from the reports of financial results and the balance sheets of the company. They have selected the key performance and solvency indicators in particular, liquidity, business
\end{abstract}

activity, profitability, solvency and investment attractiveness. Particular attention is paid to the factors of financial risk affecting the opportunities for business expansion. Econometric modeling methods were used to determine the company's development prospects that are dependent on the internal policy of cash flow management, accounts receivable, debt, external influence of inflationary risk. Research results suggest that the continuous cash flow, namely, the formation of a policy for managing accounts payable in the crisis, has a significant impact on the further development of the company.

Keywords Petrochemical Industry, Financial Stability, Financial Risk, Business Activity, Profitability, Investment Attractiveness, Performance Optimization, PJSC "SIBUR Holding"

JEL Classification: G32; Q31; Q32

\section{Introduction}

Oil and gas are the significant competitive advantage of 
many countries around the world. Over the past 40-50 years since the discovery of new oil and gas sources, thanks to the competent and targeted use of funds received from the production and export of oil and gas, such countries as Saudi Arabia, the United Arab Emirates, Qatar, Iran, Iraq, Oman, Kuwait, etc. have managed to achieve unprecedented economic, technological and scientific development.

All oil and gas producing countries are extremely dependent on the prices of raw materials in the world market. Any price change in a smaller direction has an extremely painful effect on the economic condition of countries whose budget is drawn to a greater extent at the expense of funds received from the export of hydrocarbon crude. In the modern market conditions, such situations arise quite often [1].

For many decades, the oil and gas industry has been the foundation of the economy and well-being of Russia. In the world market, the Russian Federation occupies a leading position in the production and refining of oil and gas. As the leading industry, the oil and gas sector of the economy especially attracts attention in times of economic and political instability. The global financial crisis of 2008-2009, the economic crisis of 2014-2015, as well as economic sanctions imposed in 2016, led to limited access to international capital and decreased the extraction of natural resources and the cost of energy resources, as well as to the need for a campaign of import substitution of technological equipment $[2,3]$. However, in 2019, Russia broke the post-Soviet record, reaching 568 million tons of oil and condensate. Gas production amounted to 692.33 billion cubic meters.

As for the petrochemical industry, in which chemical products are obtained on the basis of oil and gas stocks (polymer products are the result of the functioning of this industry), it is characterized by significantly greater stability and growth rates compared to most other industries, and at this stage it is among the most strategic for the Russian economy. As part of the Russian petrochemical industry development plan until 2030, the Russian enterprises are currently intensively trying to solve the problems of the industry lagging behind the world leaders through innovative development and modernization.

It should be noted that in a relatively short historical period, the petrochemical industry has taken a strong position on almost all continents. It accounts for up to $10 \%$ in the structure of the economy of many countries. Petrochemistry is the link between the oil and gas complex and other industries: the processing industry, mechanical engineering, aerospace, telecommunications and etc.

It is expected that the volume of the chemical market will double by 2030 compared to 2016 and exceed 6.3 trillion euros, opening up huge opportunities for producing countries: only China accounts for $44 \%$ of the world share, Europe-15\% (the same amount - North America). In 2018,
Europe became the second largest producer of chemical products in the world, the volume of production in monetary terms approached 550 billion euros.

The key factors of the competitiveness of petrochemical enterprises in the world are still low prices for raw materials for oil and gas processing, the cost of logistics of finished products, as well as low specific capital costs for the construction of new and expansion of existing production facilities.

At the same time, it should be taken into account that the fundamental feature of the state of the raw material base of oil and gas processing is the indicator of the availability of its own resources. Russia's supply of oil reserves at the current level of its production is 59 years, of natural gas 103 years. The refining capacities in Russia are fully provided with their own resources.

In whole, petrochemistry is considered as a way to increase the monetization of hydrocarbon raw materials due to its deeper processing. At the same time, the goals of import substitution of basic materials and increasing the export of products from processing industries are being achieved.

\section{Literature Review}

Theoretical and practical aspects of the oil and gas industry and associated risks are considered by a wide range of scholars. The findings of Lazareva [4] reflect the state of the oil industry in Russia during the crisis period. She outlines the main factors that negatively affect the industry: price fluctuations, investment dynamics and the implementation of new projects. Krasilnikov and Korosteleva [5] stress the problems of corporate management of the oil industry by evaluating the internal policy of a petrochemical firm, and the directions of its development. Mansour and Nakhle [6] consider the need for fiscal policy of the state for the stable development of the oil industry. At the same time, they argue that a sharp change in tax legislation will have a negative impact not only on the development of new deposits, but also on the revenues of oil and gas companies. Rudloff and Schulz [7] review the main types of risks that directly or indirectly affect the economic activity of oil and gas companies, among which are the politics, cyber-security, pricing, and internal corporate governance.

Bugshan, A., Lafferty, G., Barry, W., Li, Y. [8] examine the impact of the oil price crisis on revenue management behavior in the Gulf cooperation Council (GCC) countries. At the same time, the authors place special emphasis in their work on the use of different ways to manage the organization's revenue: accrual-based revenue management (AEM) and real-world revenue management (REM). Saliu, Adedeji and Ogunleye [9] consider the macroeconomic impact of oil shocks on the state's monetary policy. The study found that an expansionary 
monetary policy (in which the interest rate is lowered to encourage investments) is more effective, offsetting the negative impact of lower global oil prices. Yunusova and Loginova [10] conducted a theoretical study of the financial and economic stability of oil companies. They consider the main types of financial and economic stability of oil companies, as well as factors affecting it. Chikunov et al. [11] substantiate the need for the development of income estimates for assessing the financial risks of the oil industry. The authors use cluster analysis to propose a system of indicators that determines the level of financial risk of the Russian oil companies. Based on the method of expert assessments and fuzzy sets, classification of levels of financial risk in the oil industry is proposed. By using regression modeling, the integral level of financial risk in the oil industry is calculated and scenarios for its development for 2018-2020 are predicted. Avadhut [12] examines the theoretical justification for the need to assess the financial risks of a company from the point of view of its creditworthiness. This aspect is an important aspect of the organization's analysis, since the main source of financing for its core business is borrowed funds. Konovalova and Caplinska [13] argue that the use of borrowed funds on the one hand leads to the expansion and development of the organization's business, and on the other hand reduces the share of its equity and increases financial risks that reduce financial stability of the company. Therefore, the use of borrowed funds requires a more careful and balanced approach to the management of the organization. Another method of financing is to attract foreign direct investments. This kind of investments increases financial risks; however, it stimulates development of the financed companies [14].

In conditions of macroeconomic fluctuations, the financial and economic activity of an enterprise in a competitive environment will always be associated with a certain degree of risk. In this case, financial risks represent the greatest risk of monetary loss [15]. Therefore, it is important to assess such types of financial risks as the risk of liquidity, solvency, financial stability, as well as the risk of changing interest rates in case the company uses borrowed funds [16]. To reduce financial risks, companies utilize mergers and acquisitions, thereby creating a synergistic effect and augmenting competitiveness [17]. To help the company not only to survive in the market, but also to consolidate its positions and gain the maximum profit, the manager must be able to identify and assess risks in a timely manner and take effective managerial decisions as to minimize them [18]. This is the main task of the financial management.

Lasdon and Butler [19] consider risk management of oil refining companies. Their article identifies the main risk parameters of the company and builds a model to determine the sensitivity and impact on the financial position of the organization. Kurennoy and Golembiovskiy [20] focus on building system dynamics credit risk model of an oil company. Their study shows the possibility of using such models to define macroeconomic scenarios leading to default of a borrow. Tantau and Khorshidi [21] focus on the impact of the OPEC "containment" policy 2014-2015 on the activity of oil refiners in countries with high commodity dependence. The authors make assumptions about changing the business model of state-owned companies on the basis of which their investment attractiveness is determined. Quintino et al. [22] focus on risk management in the oil organization. The authors use the strategy of hedging the risks of the impact of fluctuations in world oil prices at the level of business units, compared with a similar strategy at the level of the organization.

\section{Materials and Methods}

To conduct a study in the field of optimizing the financial and economic activity of PJSC "SIBUR Holding" and assessing its development prospects in the context of increased financial risks, as well as constructing an optimization model and a business expansion model, the authors took materials from the consolidated financial statements in accordance with IFRS of PJSC "SIBUR Holding". In the present work, materials of various scientific journals, articles, and domain pages of websites with justifiable benefits were equally used.

The basic approach to optimizing and expanding a business is the Tuffler Bankruptcy Probability Model (1977). Moreover, the model developed by the authors of this article is based on the dependence of the organization both on its own activity and on the influence of external effects. In this regard, a model of business expansion is being built, depending on the internal policy of managing cash flows, receivables, payables, and the external influence of inflation risk.

It should be noted that the choice of PJSC "SIBUR Holding" for the analysis is not accidental. It is the largest integrated petrochemical company in Russia and one of the most dynamically developing companies in the global petrochemical industry. Its large production complex Zapsibneftekhim LLC., the largest petrochemical project in Russia since 1991, can produce annually 1.5 million tons of polyethylene of various brands, and 1 million tons of polypropylene. A significant part of the products is intended for export. About half of the export goes to China, whose market remains the most dynamic. Despite the rapid growth of its own production. There is still a significant shortage of polymers and ethylene in China. Thanks to the new capacities, Russia doubled the export of polymers and for the first time became a net exporter of them.

The most important event for the petrochemical industry in 2021 was the announcement of PJSC "SIBUR Holding" and JSC "TAIF", the large Russian group of companies that controls most of the chemical, petrochemical and oil and 
gas processing industries of Tatarstan, on the merger of petrochemical assets. Depending on the type of polymers produced, approximately $74-77 \%$ of the Russian production of polyethylene and polypropylene is accounted for by enterprises belonging to PJSC "SIBUR Holding" and TAIF Group. It is assumed that the controlling block of shares of JSC "TAIF" will be exchanged for $15 \%$ of PJSC "SIBUR Holding". As a result, an industry giant with a share of more than $75 \%$ of the Russian polymer market and a global player among the TOP-5 global manufacturers will appear.

\subsection{Overview of the world production of petrochemical products and the problems of its formation in the Russian realities}

The effectiveness of the foreign economic activity of the Russian chemical complex depends not only on the export potential of enterprises but also on the state of the global market of chemical and petrochemical products, which are determined by trends aimed at the sustainable development of the global chemical industry and the introduction of the ecosystem.

The most important trends in the development of the global chemical industry are:

1. The chemical industry is characterized by high growth rates that are ahead of the global economy. In the forecast period until 2030, the average annual growth rate of the chemical complex will exceed $4 \%$, while the average annual growth rate of the global gross domestic product (GDP) is expected to be $3 \%$.

2. The areas of application of chemical and petrochemical products continue to expand, which contributes to the innovative development of consumer sectors.

3. The countries of the European Union, the USA, and Japan specialize in the production of high-tech products of high processing, which requires significant investment in basic and applied research.
The foundations of the competitiveness of chemical complexes in these countries are the development of new types of products with advanced properties and the control of key technologies.

4. The creation of large industrial facilities to produce large-tonnage chemical and petrochemical products in China, the Middle East (Saudi Arabia, Oman, Kuwait) and Southeast Asia (Republic of Korea, Taiwan), with direct participation or under licenses of companies from developed countries, increases the potential of the chemical industry in countries and regions and contributes to the redrawing of the map of the global chemical industry towards developing countries.

The long-term analysis shows a global growth trend in the supply and demand for petrochemical products, as well as faster growth in developing regions. Global sales of chemical products are expected to reach 6.3 trillion euros in 2030. The EU chemical industry will take the third place. With $44 \%$ of the global market share, China will continue to hold first place in sales, a position previously firmly held by Europe. According to Table 1, sales of chemicals in Asia more than doubled compared to the European Union. Although competition in the Chinese chemical market is currently increasing and demand is weaker than in the past, China still offers a huge and attractive market to both chemical suppliers and consumers. In the medium term, European chemical producers are expected to benefit from a strong growth trend in China due to their high technological potential and innovative products, both through increased exports and local investments. To some extent, this depends on the competitive situation in each market segment and the development of end-consumer markets, which rely on the chemical industry - for example, consumer chemistry, automotive, electronics, food and nutrition, etc. Figure 1 shows the structure of countries with the largest increase in capital investment in petrochemical production.

Table 1. The growth in global sales of chemical products in 2007-2017, billion dollars

\begin{tabular}{|c|c|c|c|}
\hline Countries and regions & 2007 & 2017 & Share, $\%$ \\
\hline European Union, EU & 451 & 541 & 15.6 \\
\hline North American Free Trade Agreement, NAFTA & 357 & 517 & 14.9 \\
\hline Japan & 129 & 153 & 4.4 \\
\hline European countries: Switzerland, Turkey, Russia, Ukraine & 53 & 111 & 3.2 \\
\hline Latin America & 72 & 108 & 3.1 \\
\hline Asia (excluding China, India, Japan, South Korea) & 147 & 697 & 20.1 \\
\hline China & 135 & 1291 & 37.2 \\
\hline Other countries & 32 & 49 & 1.4 \\
\hline World & 1376 & 3470 & \\
\hline Russia* & 61 & \\
\hline
\end{tabular}

Source: Based on “The European Chemical News. Facts \& Figures. 2018” [23] 


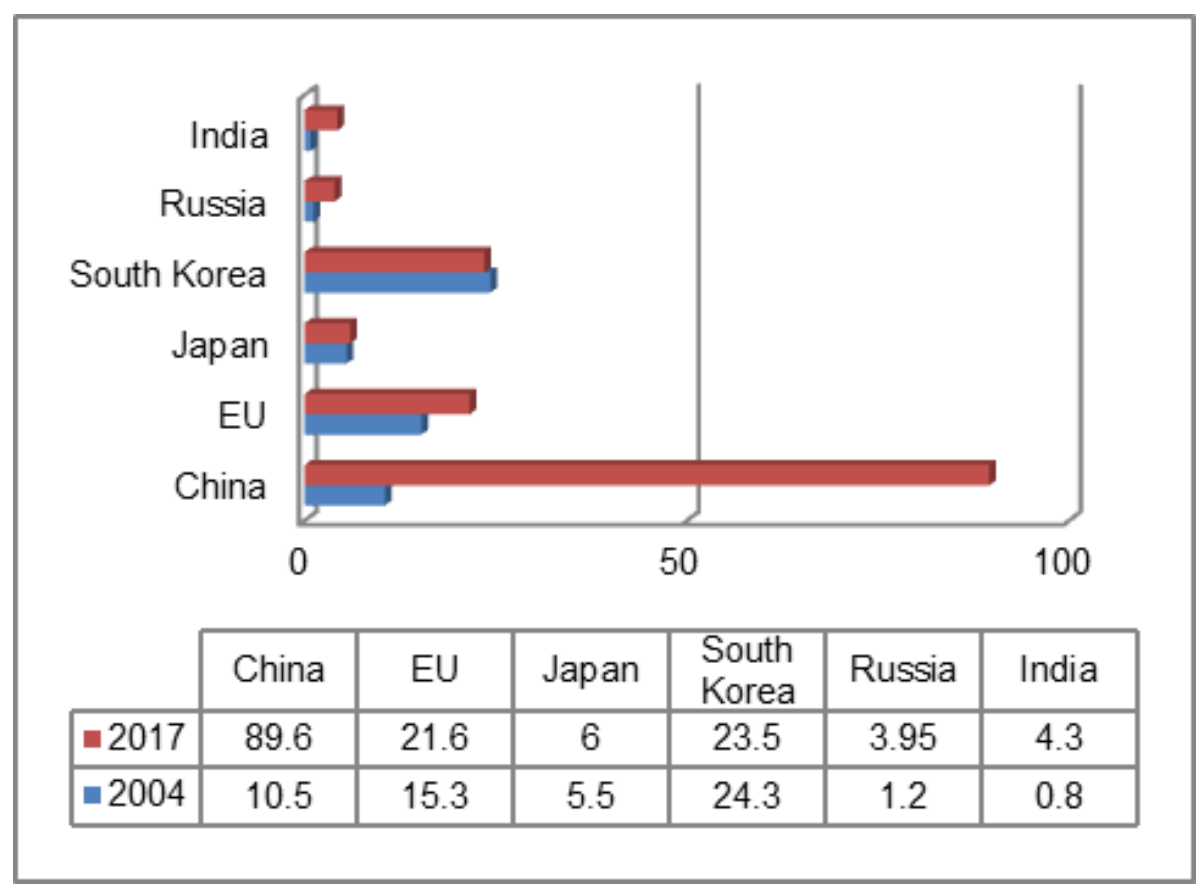

Source: Based on “The European Chemical News. Facts \& Figures. 2018” [23]

Figure 1. The volume of investments in the chemical and petrochemical industry, 2007-2017

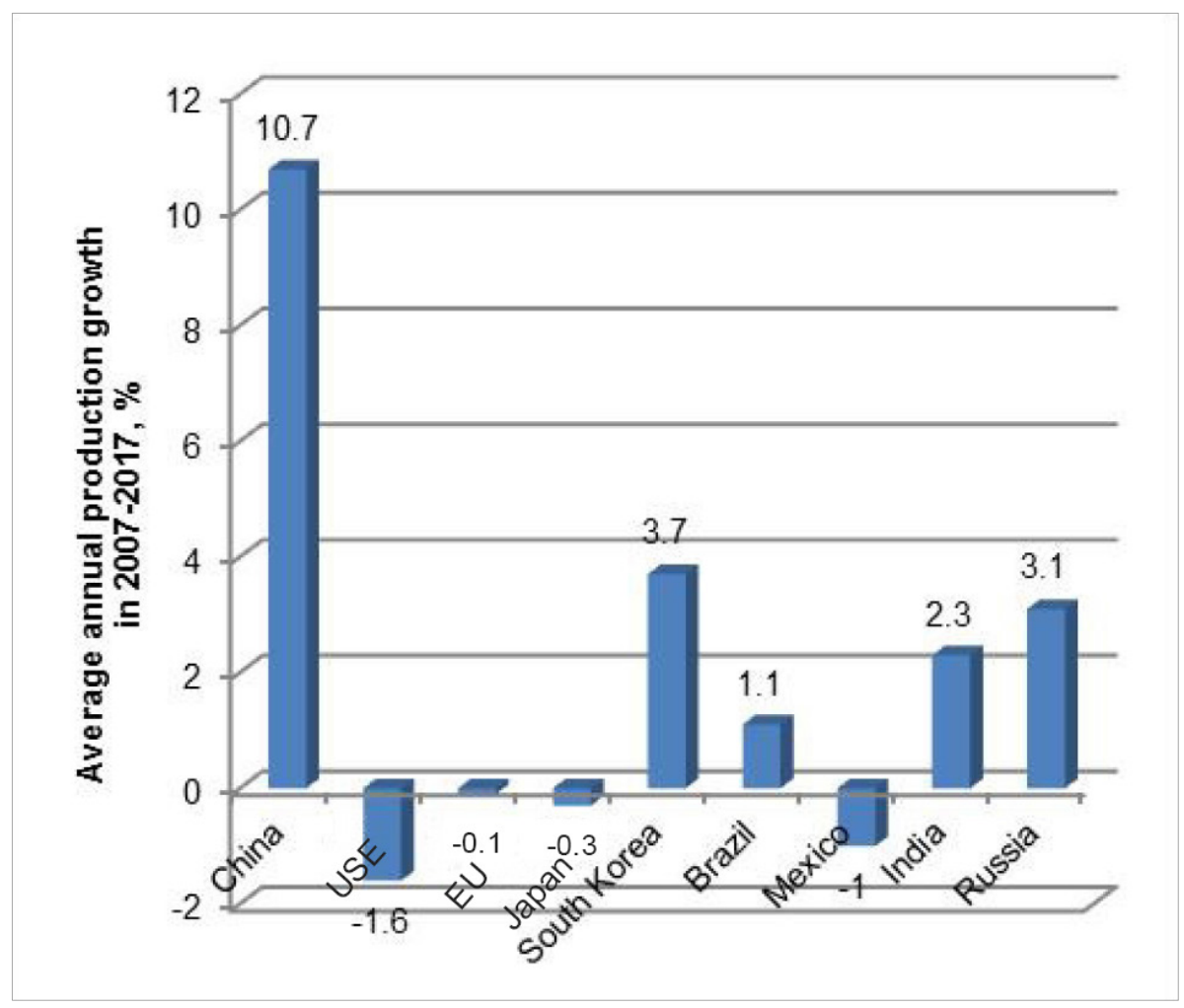

Source: Based on "The European Chemical News. Facts \& Figures. 2018” [23]

Figure 2. Countries with the highest average annual growth rate of petrochemical production, 2007-2017.

The petrochemical industry occupied one of the leading places in the national economies across the globe, especially in developing countries with a raw material development focus. The leading position in the field of investment is held by China. During 2004-2017, the volume of investments increased by 79.1 billion USD, which strengthened its leading position in the production of petrochemical products. Despite the limited financial resources due to the two past global financial crises that had a serious impact on the economy, the volume of 
investments over the thirteen-year period have increased by more than 3 times, reaching 3.95 billion USD. Figure 2 shows the top 10 countries in terms of growth in the production of chemical and petrochemical products.

The leading position in the global chemical industry is taken by China that is achieved by using "downstream" industry planning. The three following fundamental principles are key to this success:

- ensure the development of the industry to maintain growth of the national economy;

- increase the level of technology and production efficiency;

- optimize the territorial structure of the industry.

- China uses several mechanisms to stimulate the development of the chemical industry:

- $\quad$ support foreign investment;

- provide economic preferences for the expansion of manufacturing capacities and the growth of production (subsidies for leasing land plots, etc.);

- the development of chemical industrial parks (in particular, the allocation of industrial sites in three industrial zones: the Yangtze Delta and the Pearl River, Bohai Bay);

- modernization of production via $R \& D$ commercialization and support (including financial) of Chinese companies in the process of acquiring modern technologies abroad.

The prudent policy of the Chinese government has led to the fact that in the period 2007-2017 the average annual growth rate of production of chemical and petrochemical products amounted to $10.7 \%$, which significantly exceeded the same indicator in other countries of the world. According to this list, Russia occupied the 3rd place in terms of average annual production growth. The optimal investment policy and the priority strategic development of the national economy sector have made it one of the leading countries on the world stage. Though Russian chemical production occupied a leading place for certain types of products in the world market, the investment activity is low, as indicated in the dynamics of fixed capital investments (Figure 3).

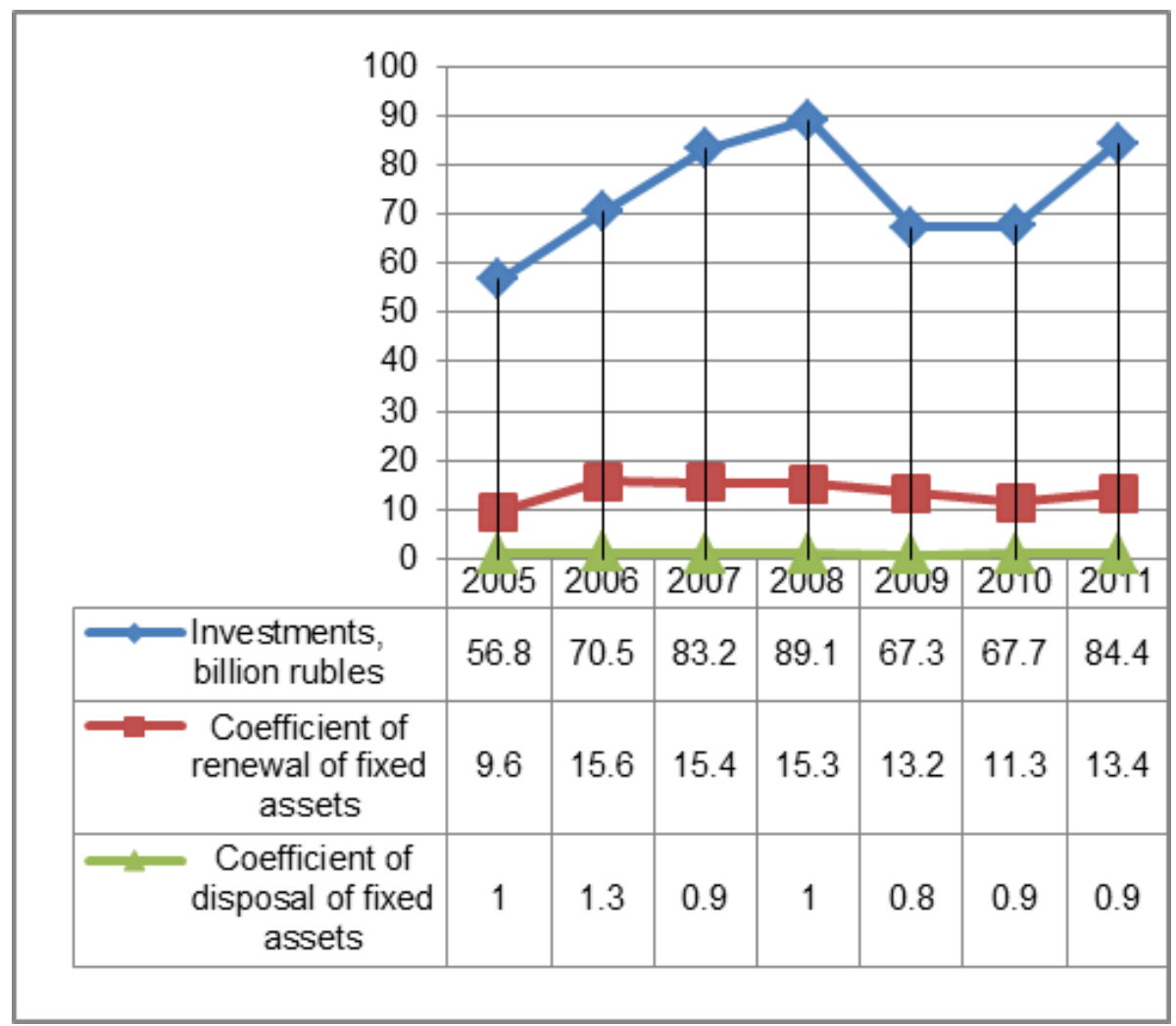

Source: Based on "Federal state statistics service" official website data [24]

Figure 3. Dynamics of fixed assets investments in 2005 prices and indicators of the movement of fixed assets of chemical production in $2005-2011$ 
Over a long period of time, the country's chemical production developed mainly at its own expense. State support was minimal and did not exceed $5 \%$ of the total amount of investments from federal sources until 2010 with an almost complete absence of funds from regional budgets. The exception was 2011, in which the following was observed: a decrease in the share of own funds with an increase in attracted funds and a sharp increase (over 7\%) in the share of public funds from regional sources. The technological backwardness of chemical production made the industry unattractive for foreign investment, and its own funds were also not enough to update its production facilities.

In the Concept of development of the chemical and petrochemical industry for the period up to 2010 ["Kontseptsiya razvitiya i neftekhimicheskoy promyshlennosti na period do 2010 goda"], developed in 2004, it was predicted that in 2010 the volume of investments in the industry will be 1.8 times higher than the level of 2005. In fact, as can be seen from Figure 1, in 2010, the consequences of the crisis were still affecting the industry, and in 2011 there was only 1.5 times more investment than in 2005. In 2008, the Strategy for the Development of the Russian Chemical and Petrochemical Industry until 2015 ["Strategiya razvitiya khimicheskoy i neftekhimicheskoy promyshlennosti Rossii na period do 2015 goda"] was approved (hereinafter referred to as the Strategy). The Strategy was developed before the crisis of 2008 , and the base year from which forecasts of the dynamics of the Strategy indicators were built was 2006 . By the time the Strategy was developed, chemical production, according to its developers, was influenced by a number of external factors, in particular:

- the growing demand for chemical and petrochemical products from the construction industry and the consumer sector, with a simultaneous decrease in the demand for mineral fertilizers;

- protectionist policies of individual states and intensive build-up of export potential in countries with cheap hydrocarbon raw materials that negatively affect the export of Russian chemical and petrochemical products.

By 2008 , negative internal factors have accumulated and were summarized in the Strategy into the systemic problem of the industry - the gap between the development of the chemical products market and the Russian chemical production. In particular, the following negative internal factors are identified: the backward assortment structure of production of most chemical enterprises of Russia, which was formed in the late 1980s and to a lesser extent consistent with the demand structure of both the external and domestic markets; high wear, besides non-progressive fixed assets, the maximum level of load of the most important types of chemical and petrochemical products; low innovation activity of enterprises; the backwardness of the Russian chemical engineering, which does not meet the contemporary challenges of chemical production.

It can be concluded that the forecasts for the development of the production of mineral fertilizers have taken into account these factors. The forecast in the Strategy stated that by 2015 the total annual (external and internal) demand for these products will amount to more than 21 million tons. Between 2006 and 2011, fertilizer production on average grew by $3 \%$ per year and reached 18.8 million tons in 2011. To achieve the forecasted demand volume, it would be enough to have an average annual growth of $2.8 \%$ for the industry from 2011 to 2015 , that is, the industry can operate without much effort in financially supporting the implementation of the Strategy.

In the State program of the Russian Federation "Development of industry and increasing its competitiveness for the period until 2020" ["Razvitiye promyshlennosti i povysheniye yeye konkurentosposobnosti na period do 2020 goda"], subprogram 13 - Chemical complex is provided. The goal of the subprogram was to develop the competitiveness of the Russian chemical complex in order to ensure the production of innovative products that can replace imported counterparts and ensure that the production, quality, and range of chemical complex products meet the demand of the Russian and world markets. The total amount of extra-budgetary investments for the implementation of investment projects and technical re-equipment activities in the chemical industry for the period up to 2020 was estimated at more than 1 trillion rubles, while government spending should have amounted to more than 17 billion rubles.

Currently, the volume of public investment in the development of the petrochemical industry is approximately 200 billion rubles. At the same time, the average growth rate, according to the developed strategy until 2030, will amount to $9.85 \%$.

The leaders of the petrochemical industry are of great strategic importance for the development of the petrochemical complex of the Russian Federation.

According to table 2, PJSC "SIBUR Holding" held a leading position in the market with revenue of 569 billion rubles. This company is of great strategic importance for the development of the petrochemical complex of the Russian Federation. Sibur Holding is a supplier of raw materials for the pipe "Purpe-South Balyk-Tobolsk" for wide fraction of light hydrocarbons with a length of about $1,100 \mathrm{~km}$ and a throughput of up to 8 million tons per year.

Thus, speaking of the priority development of the petrochemical complex in Russia, as one of the strategically important areas of economic stabilization, investing and increasing the operating activity of private companies are of particular importance, the largest and most systemically significant of which is PJSC "SIBUR Holding". 

in the Context of Increased Financial Risks

Table 2. Top-10 companies in terms of revenue in the petrochemical sector, 2018

\begin{tabular}{|c|c|c|}
\hline Company & Revenue, billion rubles & Profit, billion rubles \\
\hline PJSC “SIBUR Holding” & 569 & 106 \\
\hline EuroChem Group AG & 350 & 22 \\
\hline PhosAgro PhosAgro & 233 & 25 \\
\hline PJSC Nizhnekamskneftekhim & 194 & -9 \\
\hline PJSC Uralkali & 174 & -34 \\
\hline JSC URALCHEM OXC & 110 & 13 \\
\hline JSC Acron & 108 & 20 \\
\hline PJSC Kazanorgsintez & 79 & 7 \\
\hline OJSC Kuibyshevazot & 64 & 12 \\
\hline
\end{tabular}

Source: Based on "Russian Business Consulting" official website data [25]

Table 3. Business activity indicators of PJSC "SIBUR Holding”, 2013-2016

\begin{tabular}{|c|c|c|c|c|}
\hline Main indicators & $\mathbf{2 0 1 6}$ & $\mathbf{2 0 1 5}$ & $\mathbf{2 0 1 4}$ & $\mathbf{2 0 1 3}$ \\
\hline Inventory turnover & 15.62 & 12.11 & 13.33 & 21.81 \\
\hline Turnover of receivables & 3.43 & 3.63 & 2.85 & 1.94 \\
\hline Turnover of funds & 22.39 & 6.88 & 13.23 & 66.72 \\
\hline \multicolumn{7}{|c|}{ Turnover period } & 30.14 & 27.37 & 16.74 \\
\hline Inventory & 23.37 & 101 & 128 & 188 \\
\hline Accounts receivable & 107 & 53 & 28 & 5 \\
\hline
\end{tabular}

Source: Based on PJSC "SIBUR Holding” official website data [26]

\subsection{The Income, Expenses and Profitability of PJSC "SIBUR Holding"}

Excess of income over expenditure in the period from 2013 to 2016 testifies to the effectiveness of the system-forming organization activity. However, although the share of expenses in incomes in 2016 (by 30.12\% compared to 2015) increase, this did not affect the state of net profit [23]. The reason is that there is a more significant increase in income from participation in other organizations and other income.

It should be noted that throughout the period under review, PJSC "SIBUR Holding" was in a fairly good financial position. In 2014-2015 there was a decline in the company's activity due to economic instability in the country - the currency crisis that formed against the background of a fall in the oil prices. This, in turn, contributed to an increase in the impact of currency risk on the company's operating activity. The profitability of products and costs has declined significantly (by 24.93 and $21.05 \%$, respectively, compared to 2013). PJSC "SIBUR Holding" stabilized the situation for this group of indicators only in 2016 (product profitability -32\%, profitability $-29 \%$ ). In regard with the above, it can be concluded that the company needs to restructure its pricing policy under the influence of a sharp fluctuation in the exchange rates, which, combined with the dominant positions in the oil products market, will enable it to increase profit without loss of influence.

\subsection{Business Activity Indicators of PJSC "SIBUR Holding"}

The performance indicators of the organization, as well as its solvency, are greatly affected by the coefficients of turnover rates and the turnover period of the main items of the balance sheet and the financial results report. The development of ineffective receivables management policies leads to an increased risk of the company's solvency due to the increase in the duration of the financial cycle (tab.3).

As can be seen from Table 1, the turnover indicators were at an acceptable level during the period under study. However, one can see that in 2013, the receivables turnover was quite low $(\operatorname{Kodz}=1.94)$. This circumstance may lead to a reduction in the company's operations due to the reduction of highly liquid assets. In addition, the increase in receivables also increases the duration of the financial cycle, which is defined as the gap between the date of payment for obligations to counterparties and funds from debtors. The maximum value of the indicator was achieved in 2013 . 


\subsection{Investment Attractiveness of PJSC "SIBUR Holding"}

A stable financial condition plays an important role in the further development and expansion of the organization's activity. Therefore, it is necessary to attract additional sources of financing activity. In turn, the organization, while maintaining and carrying out stable financial activity, has a significant investment appeal. Increasing investment attractiveness allows attracting additional capital to increase technological, innovation and production potential (tab.2).

It is clear that during the economic crisis of 2014-2015 PJSC "SIBUR Holding" had a positive investment attractiveness, which attracted additional resources to expand the sales of its products and generate more profit. Effective management of financial risks in 2014-2015 has led to a significant increase in profit from sales due to fluctuations in exchange rates, which, in turn, allowed improving the investment attractiveness of the company. Reduction of financial risks and weighted average cost of raised capital increased the index of economic value added (EVA). However, the downward trend in the oil products market, as well as the reduction in supplies, led to a decrease in sales revenue in 2016, which led to a sharp decline in EVA.

\subsection{Assessment of Liquidity and Insolvency Risk of PJSC "SIBUR Holding"}

The financial condition of the organization is greatly influenced by the liquidity of its balance sheet, since it is an indication of its solvency. As a result, it affects the ability of the organization to meet its liabilities generated through the implementation of passive operations. Maintaining the optimal level of liquidity and quality of balance assets is one of the primary tasks of the company.

According to the consolidated financial statements of PJSC "SIBUR Holding", over the period the investments in research and development (R\&D) have grown at a significant pace (an average growth of over 50\%). As for current assets, in 2016 there was a significant increase in accounts receivable $-11 \%$. The total balance sheet currency, despite a decrease in short-term financial investments and cash, increased by $5.72 \%$ compared to 2015.

Having grouped the assets by liquidity degree, it is clear that hard-to-sell assets grew at the highest rates from 2013 to 2016 (the average growth rate was $135.14 \%$ ). The increase in this expense is associated with an increase in R\&D, the annual increase of which, as mentioned above, averaged to $50.67 \%$. The annual increase in hard-to-sell assets leads to a liquidity risk, which significantly affects the solvency of the Holding and the fulfilment of its obligations. Regarding the equity distribution, the largest share in the structure of absolutely liquid assets belonged to cash. As of 2016, this indicator is 73.02\%. A2-other current assets (67.43\%), A3-receivables long-term (81.53\%), A4financial investments $(97 \%)$.

Over the period under review, estimated liabilities grew at a significant pace, both long-term and short-term (on average, growth was over $4041 \%$ and $1491 \%$ ). These values are associated with a sharp increase in indicators in 2016 (119955\% and 1598\%).

The main share in the balance sheet structure was held by capital and reserves. As of 2016, this is $44.35 \%$. The largest share, both in the structure of liabilities and in the balance sheet, belonged to the accounting article "Borrowed funds" (over 95\% and 58\% in the structure of long-term and short-term liabilities, 35\% in the balance sheet structure as a whole).

The balance cannot be considered absolutely liquid throughout the entire period, that is, in the period 2013-2016 PJSC "SIBUR Holding" did not have long-term solvency. In addition, in 2015-2016 violations of the short-term solvency conditions were observed, which could significantly affect the financial stability of the company.

Table 4. Dynamics of liquidity and solvency indicators of PJSC "SIBUR Holding" in 2013-2016

\begin{tabular}{|c|c|c|c|c|c|c|c|}
\hline Main indicators & 2016 & 2015 & 2014 & 2013 & 2012 & 2011 & Normative values \\
\hline absolute liquidity (L2) & 0.19 & 1.08 & 0.45 & 0.25 & & & $>0.2-0.7$ \\
\hline quick liquidity (L3) & 1.12 & 1.86 & 1.61 & 1.84 & & & $>=1.5$ \\
\hline current liquidity (L4) & 1.33 & 2.11 & 1.86 & 2.01 & & & $>=2$ \\
\hline own funds (L5) & -1.23 & -0.42 & -0.56 & 0.10 & & & $>=0.1$ \\
\hline capital maneuverability (L6) & 0.63 & 0.22 & 0.30 & 0.17 & & & \\
\hline restoration of solvency & 0.47 & 1.11 & 0.90 & & & & $>=1$ \\
\hline loss of solvency & 0.57 & 1.08 & 0.91 & & & & $>=1$ \\
\hline total liquidity ratio & 0.66 & 1.40 & 1.03 & 1.47 & 0.92 & 3.30 & $>=1$ \\
\hline
\end{tabular}

Source: Based on PJSC "SIBUR Holding” official website data [26] 
According to Table 3, PJSC "SIBUR Holding" meets the regulatory requirements for liquidity and solvency of the organization. With that, some difficulties are registered in 2016. In this period, the main performance of the organization significantly deviated from normal values and even approached the critical level.

In this regard, we decided to assess the probability of insolvency for the next period. To do this, the Springate's $\mathrm{Z}$-score predictive model of solvency risk was used. This model is built on the basis of a sample of 40 companies and the forecast accuracy is at the level of $92.5 \%$. The assessment of the insolvency probability for this model is made by the following formula:

$$
Z=1.03 X_{1}+3.07 X_{2}+0.66 X_{3}+0.4 X_{4}
$$

After conducting preliminary calculations, it can be concluded that, despite the significant deviation of liquidity from normal values, PJSC "SIBUR Holding" has a low risk of solvency loss, since it's predictive value of calculated for $2017(\mathrm{Z} 2017=1.389206) 1.61$ times exceeds the value reflecting the high risk of loss of solvency of the organization $(\mathrm{Z}<0.862)$.

For a more specific assessment of the company's financial stability [27], we use Tuffler's method for calculating the probability of bankruptcy, which was developed by Richard Tuffler in 1977 on the basis of a sample of 92 companies. The probability of bankruptcy by this method is calculated by the formula:

$$
Z=0.53 K_{1}+0.13 K_{2}+0.18 K_{3}+0.16 K_{4}
$$

According to the calculations, PJSC "SIBUR Holding" has a low level of risk of losing financial stability. Throughout the period under review, the Tuffler coefficient averaged 0.61 , which is more than twice the recommended value $(>=0.3)$.

\section{Results}

To maximize profits, the management of the organization at the same time seeks to minimize the possibility of losses. Maintaining the optimal balance between profitability and risk is one of the main and most complex problems of managing the company. Identification of development prospects is closely related to the effectiveness and quality of the analysis of the financial condition of the company of previous years, affecting the priority areas of development and improvement of its activity being highlighted.

Determining the financial result of an organization depends on many factors, but, generally, an increase in the risk of an activity leads to an increase in its profitability. According to the data calculated from the consolidated financial statements, the margin of PJSC «Sibur Holding» in 2014 amounted to $32.71 \%$ with a value of operating leverage of 1.85 . However, knowing the specifics of the organization and calculating the relevant indicators in the distribution by segment, it is possible to increase the profitability of the company while reducing the risk indicator during portfolio restructuring.

One of the methods for solving this problem is the application of the optimization problem.

Description of the task: the degree of operating leverage (DOL) risk depends on the amount of revenue, the ratio of variable and fixed costs, as well as production efficiency. When determining the structure of production, it is necessary to ensure maximum economic efficiency with minimal risk.

To solve this problem, the following information is required in terms of unit of production:
- $\quad$ Price
- Variable costs
- $\quad$ Fixed costs
- Margin
- $\quad$ EBIT

All raw and auxiliary data required are given in table 5 .

Table 5. Input research data

\begin{tabular}{|c|c|c|c|c|c|}
\hline 2014 (price) & Revenue & Variable costs & Fixed costs & MR & EBIT \\
\hline Gas processing and infrastructure & 7076.20 & 4888.87 & 936.07 & 2187.34 & 1251.27 \\
\hline $\begin{array}{c}\text { Olefins and polyolefins } \\
\begin{array}{c}\text { Plastics, elastomers and intermediates } \\
+ \text { other }\end{array}\end{array}$ & 29199.14 & 20174.44 & 3862.80 & 9024.70 & 5161.90 \\
\hline Result & 36164.15 & 15715.79 & 3009.10 & 14448.36 & 11439.25 \\
\hline
\end{tabular}

Source: Based on PJSC “SIBUR Holding” official website data [26]. 
In order to find a solution to the problem, it is necessary to formulate a mathematical model. First of all, we write it in a general form, using the following notation:

$\mathrm{N}$ is the set of manufactured products, $\mathrm{j} \in \mathrm{N}$;

$M$ - all resources that can be distributed between different types of products, i€M;

Aij - costs of the i-th resource to produce the j-th product;

$\mathrm{Bj}$ - revenue of the $\mathrm{j}$-th type of product;

$\mathrm{Pj}$ - price of $\mathrm{j}$-th product

$\mathrm{Dj}$ - the cost of the j-th type

$\mathrm{Cj}$ - margin received from the $\mathrm{j}$-th product;

$\mathrm{Ej}$ - EBIT received from the $\mathrm{j}$-th product.

Variable tasks (controlled, sought quantities):

$\mathrm{Xj}$ - production volume of the $\mathrm{j}$-th product

The general model of the problem is as follows:

Target function:

$$
\sum \frac{\mathrm{Cj} * \mathrm{Xj}}{\mathrm{Ej} * \mathrm{Xj}} \rightarrow \min
$$

Limitations on the number of resources used:

$$
\sum A i j * X j \leq D j
$$

Limitations on revenue:

$$
\sum P i j * X j \leq B j
$$

In order to get the results in the right form during the decision process, we introduce an additional restriction into the model related to the condition of integer values of variables: $\mathrm{Xj} \in \mathrm{Z}$

The structure of the optimization model of PJSC "Sibur Holding" is as follows:

Target function:

$$
\frac{M R}{E B I T} \rightarrow \min
$$

Limitations to:

total revenue:

$$
\text { 7076.2X1+29199.14X2+30164.15X3 } \leq 361000
$$

total variable costs:

4888.87X1+20174.44X2+15715.79X3 $\leq 242899$

total fixed costs:

$936.08 \mathrm{X} 1+3862.8 \mathrm{X} 2+3009.1 \mathrm{X} 3 \leq 54282.51$ integer values:

$\mathrm{X} 1, \mathrm{X} 2, \mathrm{X} 3$ - integer values

where, $\mathrm{X} 1$ - production volume of the Gas Processing and Infrastructure segment; X2 - production volume of the Olefins and Polyolefins segment; X3 - production volume of the Plastics, Elastomers and Intermediates segment.

According to the generated optimization problem and the calculations, we have the following results (see Table 6).

The optimization task formed led to a decrease in the operating leverage of the organization by 0.49 compared to the actual value of 2014 (1.85). The decrease occurred, as noted above, as a result of portfolio restructuring. Due to the redistribution of production, costs were reduced, which allowed increasing sales margins by $9 \%$. Despite the positive dynamics of operating profit in 2014 (17.68\%) when adjusting this value for DOL, the net profitability will become $9.55 \%$, which makes this company less attractive for investment. However, taking into account the indicators found, the risk-adjusted profitability would be equal to $22.16 \%$, which is $12.6 \%$ above actual value. The emphasis was placed on the production of high-tech products, as a result of which the company would have avoided the need to actively build up its raw material base, which would reduce its costs while maintaining revenue at the current level.

The financial status of an enterprise is significantly influenced by the amount of revenue. As a consequence, the cash flow enables a horizontal-integral policy in the area of business expansion. A basic business expansion model is built based on the aggregate internal cash flow management policy formed, accounts receivable, accounts payable and external influence of inflation risk requires application of multiple regression equation. The multiple regression equation:

$$
\mathrm{Y}^{\wedge}=\mathrm{a}+\mathrm{b}_{1} * \mathrm{X}_{1}+\mathrm{b}_{2} * \mathrm{X}_{2}+\mathrm{b}_{3} * \mathrm{X}_{3}+\mathrm{b}_{4} * \mathrm{X}_{4}
$$

In the given equation $\mathrm{b} 1, \mathrm{~b} 2, \mathrm{~b} 3$ and $\mathrm{b} 4$ are coefficients of inclination factors $\mathrm{X}$; $\mathrm{a}$ is a free coefficient that does not have units of measure and may not have economic meaning.

\begin{tabular}{|c|c|c|c|c|c|c|}
\hline 2014 (price) & Revenue & Variable costs & Fixed costs & MR & EBIT & DOL \\
\hline Gas processing and infrastructure & 7076.20 & 4888.87 & 936.07 & 2187.34 & 1251.27 & 1.748 \\
\hline Olefins and polyolefins & 29199.14 & 20174.44 & 3862.80 & 9024.70 & 5161.90 & 1.748 \\
\hline $\begin{array}{c}\text { Plastics, elastomers and } \\
\text { intermediates+other }\end{array}$ & 30164.15 & 15715.79 & 3009.10 & 14448.36 & 11439.25 & 1.263 \\
\hline Result & 361000.00 & 242899.00 & 54282.51 & 118101.0 & 63818.49 & \\
\hline Calculated value & 360999.98 & 211077.15 & 40414.96 & 149922.8 & 109507.9 & 1.369 \\
\hline
\end{tabular}

To construct a model for the dependence of the resulting indicator Y, micro- and macroeconomic factors were systematized over a certain period, directly or indirectly affecting it (Table 7).

Table 6. Productive value of the optimization problem

Source: Based on PJSC “SIBUR Holding” official website data [26]. 
Table 7. Dynamics of macroeconomic factors of PJSC "SIBUR Holding" in 2011-2016

\begin{tabular}{|c|c|c|c|c|c|}
\hline Year & Revenue & Cash assets & $\begin{array}{c}\text { Overdue accounts } \\
\text { receivable }\end{array}$ & $\begin{array}{c}\text { Overdue accounts } \\
\text { payable }\end{array}$ & $\begin{array}{c}\text { Consumer price } \\
\text { index }\end{array}$ \\
\hline 2011 & 238534266 & 4248775 & 7469206 & 0 & 1.061 \\
\hline 2012 & 243328982 & 2410558 & 86848 & 3825 & 1.0657 \\
\hline 2013 & 243208964 & 3645260 & 2150660 & 4665 & 1.0647 \\
\hline 2014 & 285545215 & 21588694 & 631710 & 229105 & 1.1135 \\
\hline 2015 & 344525645 & 50098058 & 862656 & 199795 & 1.1291 \\
\hline 2016 & 361485474 & 16142132 & 509972 & 1366063 & 1.0539 \\
\hline TOTAL & 1716628546.0 & 98133477.00 & 11711052.00 & 1803453.00 & 6.49 \\
\hline Average & 286104757.67 & 16355579.50 & 1951842.00 & 300575.50 & 1.08 \\
\hline
\end{tabular}

Source: Based on PJSC “SIBUR Holding” official website data [26]

Table 8. Testing the significance of regression equation coefficients

\begin{tabular}{|c|c|c|c|c|}
\hline Indicator & Coefficients & Standard Error & t-statistics & P-Value \\
\hline Y-intersection & 571861641.7 & 17311433.45 & 33.0337544 & 0.0192659 \\
\hline Cash assets & 2.314143592 & 0.025978752 & 89.0783213 & 0.0071464 \\
\hline Overdue accounts receivable & -1.376293809 & 0.073353616 & -18.7624534 & 0.0338984 \\
\hline Overdue accounts payable & 61.27312949 & 0.534764839 & 114.579578 & 0.0055559 \\
\hline Inflation & -313818280.5 & 16197271.35 & -19.3747622 & 0.0328290 \\
\hline
\end{tabular}

Source: Based on PJSC “SIBUR Holding” official website data [26]

Table 9. Correlation analysis of the regression equation's factors

\begin{tabular}{|c|c|c|c|c|c|}
\hline Indicator & Revenue & Cash assets & $\begin{array}{c}\text { Overdue accounts } \\
\text { receivable }\end{array}$ & Overdue accounts payable & Inflation \\
\hline Revenue & 1 & & & & \\
\hline Cash assets & 0.7328 & 1 & & & \\
\hline Overdue accounts receivable & 0.4741 & -0.3398 & 1 & & \\
\hline Overdue accounts payable & 0.7824 & 0.1550 & -0.33595 & -0.245525 & 1 \\
\hline Inflation & 0.352205 & 0.8519 & -0.31994 & & 1 \\
\hline
\end{tabular}

Source: Based on PJSC "SIBUR Holding” official website data [26]

The model is based on the amount of revenue, which we denote by Y. Factors are taken: X1 - cash (thousand rubles); $\mathrm{X} 2$ - overdue accounts receivable; X3 - overdue accounts payable, expressed in monetary terms; X4 - Inflation risk.

To find the parameters of the linear multiple regression equation, the following formulas are used:

$$
\begin{gathered}
\mathrm{b}_{1}=\frac{\sigma_{\mathrm{y}}}{\sigma_{\mathrm{x}_{1}}} * \frac{\mathrm{r}_{\mathrm{yx}_{1}}-\mathrm{r}_{\mathrm{yx}_{2}} * \mathrm{r}_{\mathrm{x}_{2} \mathrm{x}_{1}}}{1-\mathrm{r}^{2} \mathrm{x}_{2} \mathrm{x}_{1}} \\
\mathrm{~b}_{2}=\frac{\sigma_{\mathrm{y}}}{\sigma_{\mathrm{x}_{2}}} * \frac{\mathrm{ryx}_{\mathrm{yx}_{2}}-\mathrm{r}_{\mathrm{yx}_{1}} * \mathrm{r}_{\mathrm{x}_{2} \mathrm{x}_{1}}}{1-\mathrm{r}^{2} \mathrm{x}_{2} \mathrm{x}_{1}} \\
\mathrm{a}=\mathrm{Y}_{\mathrm{av} .}-\mathrm{b}_{1} * \mathrm{X}_{1 \mathrm{av}}-\mathrm{b}_{2} * \mathrm{X}_{2 \mathrm{av}}
\end{gathered}
$$

After finding the regression coefficients, the equation is as follows:

$$
\begin{array}{r}
Y^{\wedge}=571861641.7+2,3141 X_{1}-1.376293809 X_{2} \\
+61.27312949 X_{3}-313818280.5 X_{4}
\end{array}
$$

The coefficient of the factor $\mathrm{X} 1$ shows that when it increases to 1 billion rubles the revenues volume increases by over 2 billion rubles at zero value of the remaining factors (Table 8).

It can be seen from the table data that the coefficients at factors $\mathrm{X} 1$ and $\mathrm{X} 3$ are significant, as $|\operatorname{tstat}|>\operatorname{tcrit}(1 \% ; 6)$. The free coefficient and coefficients for factors X2 and X4 turned out to be significant at the $5 \%$ level, as $\mid$ tstat $\mid>$ tcrit $(1 \% ; 6)$.

To determine the functional connection in economic and mathematical modeling, the concept of correlation is used.

Based on the table 9, it can be seen that cash and overdue accounts payable have a strong relationship with the result. However, factors $\mathrm{X} 1$ and $\mathrm{X} 3$ have a rather weak relationship. A similar statement can be made about the relationship between the factor $\mathrm{X} 4$ and the result $(\mathrm{Y})$.

When constructing any model, it is important to evaluate the reliability of the equation. This process is described by the Fisher distribution.

$$
\mathrm{F}=\frac{R^{2} y x_{2} x_{1}}{1-R^{2} y x_{2} x_{1}} * \frac{n-m-1}{m}
$$

In our case, the actual distribution of the F-criterion of Fisher is: 


$$
\mathrm{F}=\frac{0.9999}{1-0.9999} * \frac{6-4-1}{4}=27593.9852
$$

Comparing this value with the tabular (5624.58333), we can conclude that there is no coincidence of obtaining this value of the Fisher criterion. It was formed under the influence of significant factors, which confirms the statistical significance of the equation, as well as the relation tightness indicator.

When constructing a model, one should evaluate the feasibility of including a factor in the multiple regression equation. This assertion is verified on the basis of finding Fisher's particular criteria.

After making preliminary calculations, we have obtained that Fpart, $\mathrm{x} 2=153278.6942$, Fpart, $\mathrm{x} 1=$ 256702.8131, Fpart, $\mathrm{x} 3=128423.3118$, Fpart, $\mathrm{x} 4=$ 290051.4246. Comparing these indicators with the tabulated value (5624.58333), it is evident that the expediency including all the above selected factors in the equation is confirmed.

Having identified the expediency of inclusion of factors, as well as the importance of the equation for finding the forecast value of revenue, we use the equation of multiple linear regression.

A point forecast of the value of the resultant characteristic is made based on the predicted values of the factors affecting this indicator. As a result, the value of factor $\mathrm{X}$, in the linear pair regression model, is replaced by its predicted value $\mathrm{X}$ forecast for a certain period.
To the following formulas are used:

$$
\overline{\mathrm{Y}}=\mathrm{a}+\mathrm{bt}
$$

Having made the necessary calculations, we obtained the forecasted value of revenue factors for 2017-2018. As a result, after substituting the forecast factors' values of 2017 into the equation $\mathrm{Y}$, the amount of revenue amounted to 373811481.3 thousand rubles. According to the forecast, PJSC "SIBUR Holding" will keep the trend of revenue increase and by 2018 will reach 395738162.3 thousand rubles, which is by 34253311.24 thousand rubles more than in 2016, and taking into account the coefficient of reliability of approximation, the probability of obtaining this amount is $98.05 \%$.

However, in order to determine the reliability of the forecast, it is necessary to determine the standard error of the forecast

$$
S E\left(Y^{\wedge *}\right)=\mathrm{s}_{\varepsilon} \sqrt{1+\frac{1}{n}+\frac{\left(X^{*}-X_{a v}\right)^{2}}{\sum_{i}^{n}\left(X_{i}-X_{a v}\right)^{2}}}
$$

The forecast error is 49286196.49 units and it will increase as the predicted value of the factor moves away from the average value of the factor by the sample population.

Interval forecast at $\gamma \%$ level is determined by the following formula:

$\mathrm{Y}^{\wedge *-\mathrm{SE}}\left(\mathrm{Y}^{\wedge *}\right) * \operatorname{tcrit}(\gamma \gamma ; \mathrm{df})<\mathrm{Y}>\mathrm{Y}^{\wedge *+\mathrm{SE}}\left(\mathrm{Y}^{\wedge *}\right) * \operatorname{tcrit}(\gamma \gamma ; \mathrm{df})$

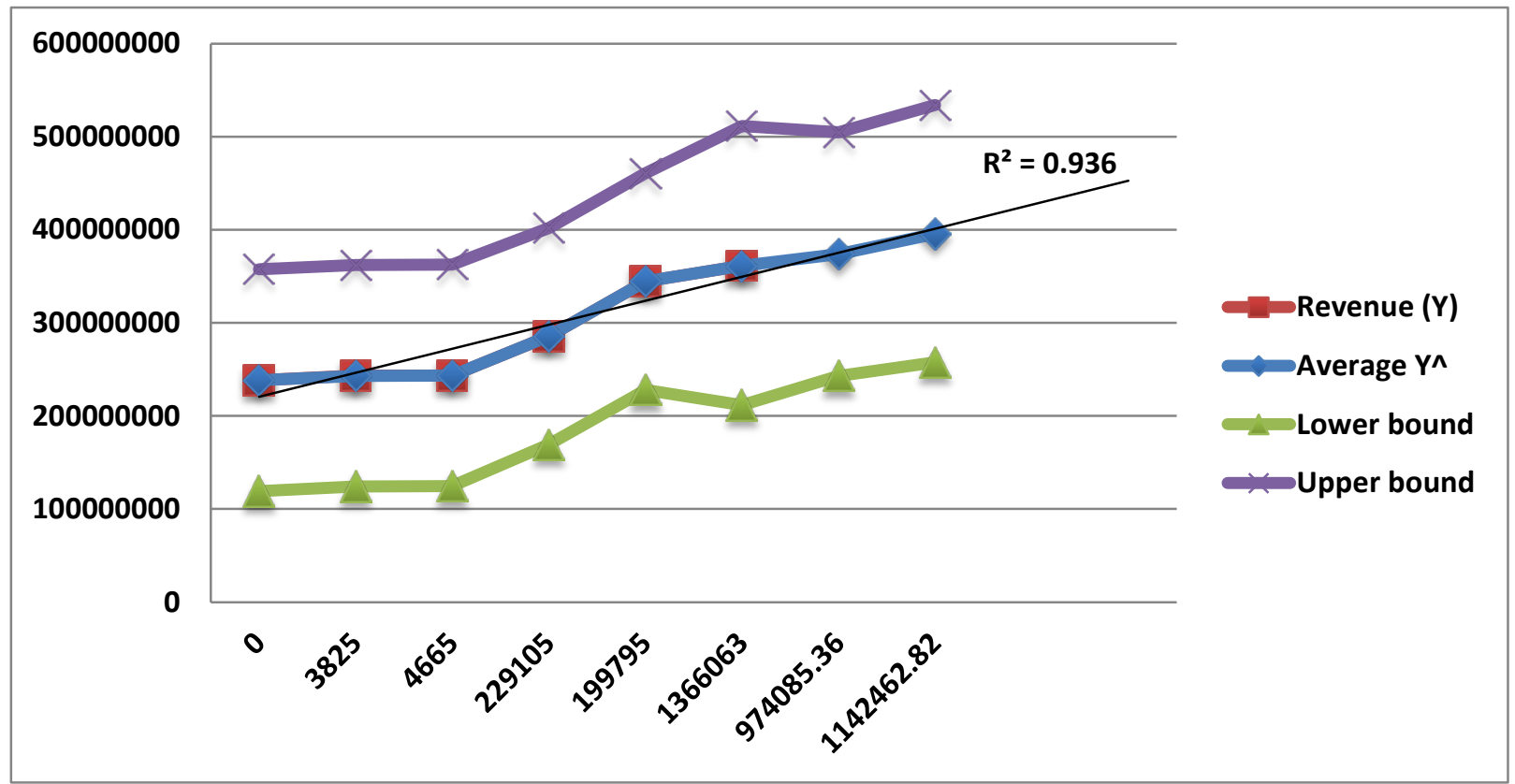

Source: Based on PJSC "SIBUR Holding" official website data [26]

Figure 4. Confidence intervals for the forecast 
Figure 4 shows that the amount of revenue of PJSC "SIBUR Holding" is within the lower and upper limits for the entire period under review. This fact confirms both the effectiveness of the organization's policy in the oil refining industry and the developed strategy. Given the normal distribution of balances with an average value of the number of overdue accounts payable equal to 300575.5 thousand rubles with a probability of 0.94 , the projected amount of interest income will be from 243135007.74 thousand rubles up to 504487954.93 thousand rubles in 2017 , with a conditional average (the most likely amount of income) expected at a rate of 373811481.34 thousand rubles.

\section{Conclusion and Further Research}

Formation of an effective business strategy is a complex process that occurs under the influence of a number of factors. Classification of factors allows for a deeper understanding of their internal content. Traditionally, they are divided into macro- and microeconomic. It is external factors that have a more significant impact on the financial condition of an individual enterprise. Characteristic features are the properties, mutual correlation, multidirectional. The factors influence both the growth and de-cline in volumes, which manifests their ambivalence.

In the framework of this work, a basic model of revenue dependency is constructed, based on the aggregate of the internal policy of cash flow management, accounts receivable, accounts payable and external influence of inflation risk. In the course of mathematical calculations, it was possible to establish the significance and stability of the model as a whole, as well as the need to include all of the above factors in the model. Taking into account the value of the Fisher distribution (27593.9852), the factors selected in the model turned out to be significant.

As a result of the correlation, a strong relationship is established between the volume of revenue, cash and overdue payables (at the level of 0.75 ).

Despite the crisis, there is a positive outlook for the volume of revenue of PJSC "SIBUR Holding" for the next few years.

The crisis of 2020, when the demand and prices for hydrocarbons collapsed under the influence of the COVID-19 pandemic, drew attention to the development of oil and gas chemistry in Russia. In contrast to the decline in capacity utilization among the European and American manufacturers, Russia has experienced a significant increase in production volumes in a number of areas. As a result, in 2020, PJSC "SIBUR Holding" became the largest polymer manufacturer in Russia with a share of about $60 \%$, surpassing the former industry leader -TAIF Group in terms of volumes. In 2020, its revenues amounted to 7.2 billion USD, EBITDA - 2.5 billion USD.

To increase investment attractiveness and stabilize the financial situation, it is necessary, first of all, to increase the cost of equity by replenishing reserve capital. In addition, the company should reduce the share of long-term financial investments in the structure of the balance sheet assets, which will allow it to increase profits through speculative operations in the stock market and use part of the money to reduce liabilities. Thus, based on the analysis, we can conclude that the indicators of PJSC "SIBUR Holding" are consistent and stable, and on the basis of the forecasts made, the ability of the company to retain its leading positions in the market are revealed.

The results of this analysis can be used to further explore the issues of the financial condition and management of financial risks.

\section{Acknowledgments}

This paper has been supported by the RUDN University Strategic Academic Leadership Program (recipient Oksana Savchina).

\section{REFERENCES}

[1] Savchina, O., et al. Assessment of Financial Stability and Business Expansion of JSC Statoil in the Context of Economic Instability. Journal of Advanced Research in Law and Economics, Volume X, 6(44), 1929 - 1938, 2019, DOI: https://doi.org/10.14505/jarle.v10.6 (44).35. Online available from: http://journals.aserspublishing.eu/jarle/index. (accessed 17 April 2021).

[2] Savchina, O.V.; Savchina, O.V.; Asinovich, A.V.; Kosyakov, M.A.; Bobkov, A.L. Energy Sector of the Russian Federation in the Context of Macroeconomic Instability. International Journal of Energy Economics and Policy, Vol.7 (5), 28-33, 2017.

[3] Savchina O.V.; Pavlinov D.A.; Savchina O.V. Financial Stability of Electricity Companies in the Context of the Macroeconomic Instability and the COVID-19 Pandemic. International Journal of Energy Economics and Policy, Vol.11 (5), 85-98, 2021.

[4] Lazareva, N.V. Problems and prospects of development of the Russian oil industry. KANT. Vol.1(1), 28-33, 2014.

[5] Krasilnikov, A.V.; Korosteleva, V.V. Small business of the oil industry: experience and problems of development. Problems of modern economics, Vol.3, 198-200, 2010.

[6] Mansour, M., Nakhle, C. Fiscal stabilization in oil and gas contracts: evidence and implications. Oxford institute for energy studies, 2016, Online available from: https://www.oxfordenergy.org/wpcms/wp-content/uploads/2 016/02/Fiscal-Stabilization-in-Oil-and-Gas-Contracts-SP-37 .pdf. (accessed 11 November 2017).

[7] Rudloff, D.; Schultz, M. How oil and gas companies gauge the risks they face. Oil \& gas financial journal, Vol.13(9), 2016, Online available from: http://www.ogfj.com/articles/p 
rint/volume-13/issue-9/features/top-risks-in-oil-and-gas.htm 1. (accessed 14 November 2020).

[8] Bugshan, A.; Lafferty, G.; Bakry, W.; Li, Y. Earnings Management During the oil Price Crisis. Journal of Applied Economic Sciences, Vol.2(68), 297-309, 2020, DOI: https://doi.org/10.14505/jaes.v15.2 (68).04 (accessed 25 October 2020).

[9] Saliu, M.O.; Adedeji, A.S.; Ogunleye, E.O. Crude oil price shocks, monetary policy and output growth in African oil producing countries. Journal of Applied Economic Sciences/ Vol.1(67), 219-228, 2020, DOI: https://doi.org/10.14505/jae s.v15.1 (67). 20 (accessed 25 October 2020).

[10] Yunusova I. R.; Loginova V. G. Research of financial and economic stability of oil companies as a tool of corporate control and analysis. Herald of Science and Education, Vol.20-2(74), 37-39, 2019, Online available from: https://cyberleninka.ru/article/n/research-of-financial-and-ec onomic-stability-of-oil-companies-as-a-tool-of-corporate-co ntrol-and-analysis/viewer (accessed 25 October 2020).

[11] Chikunov, S.O.; Pankratov, V.V.; Sokolov, A.A.; Pozdyaev, A.S.; Osinovskaya, I.V.; Ivleva, M.I. Financial risks of Russian oil companies in conditions of volatility of global oil prices, 2019, Online available from: https://elibrary.ru/item. asp?id=37223733 (accessed 25 October 2020).

[12] Avadhut. Financial Risk Analysis - A Complete Guide, 2020, Online available from: https://www.financewalk.com/financ ial-risk-analysis/ (accessed 25 October 2020).

[13] Konovalova N.; Caplinska A. Impact Analysis of Factors Influencing Bank Capital Management. Journal Entrepreneurship and Sustainability Issues, Vol 8 (1), 2020, pp. $484-495$, ISSN 2345-0282, DOI: https://jssidoi.org/jesi/article/634. Online available from: https://jssidoi.org/jesi/uploads/articles/29/Konovalova_Impa ct analysis_of_factors influencing_bank_capital_managem ent.pdf. (accessed 30 January 2021)

[14] Saksonova S. Foreign direct investment attraction in the Baltic States. Journal Business: Theory and Practice, Vol 15, No 2, 2014, pp.114-120, ISSN: 1648-0627, DOI: https://doi.org/10.3846/btp.2014.11

[15] Ryaskova, N. Financial risks, their nature and classification. Rossiiskii bukhgalter, Vol.12, 94-108, 2015.

[16] Konovalova N. Management of liquidity and profitability in commercial banks. Lecture Notes in Networks and Systems, Springer International Publishing, Book series (LNNS, volume 68), 2019, pp. 725-736. Online available from: https://link.springer.com/chapter/10.1007\%2F978-3-030-12 450-2_70. (accessed 21 April 2021).
[17] Saksonova S.; Kantāne I. Mergers and acquisitions: Examples of best practice in Europe and Latvia, Contemporary Studies in Economic and Financial Analysis, Vol. 98, Emerald Group Publishing Limited, Bingley,2016, pp. 95-110, ISBN: 978-1-78635-907-0, https://doi.org/10.11 08/S1569-375920160000098007

[18] Maksimova, O. How to reduce the company's financial risks, or What is financial risk and how to deal with it?', 2005, Available online: http://hr-portal.ru/article/kak-snizit-finans ovye-riski-kompanii-ili-chto-takoe-finansovyy-risk-i-kak-snim-borotsya. (accessed 08 September 2019).

[19] Lasdon, L.S.; Butler, J.C. Risk Management of Oil Refinery, 2014, Online available from: https://repositories.lib.utexas.e du/bitstream/handle/2152/26105/DO-THESIS-2014.pdf?seq uence $=1$ (accessed 08 September 2020).

[20] Kurennoy, D.S.; Golembiovskiy, D.Yu. System dynamics credit risk model of an oil company. Scientific and practical journal: issues of risk analysis, Vol.14(1), 6-22, 2014, Online available from: https://www.risk-journal.com/jour/article/vi ew/65?locale $=$ en_US (accessed 11 November 2019).

[21] Tantau, A.D.; Khorshidi, M. New business models for state companies in the oil industry. Management \& Marketing. Challenges for the Knowledge Society, Vol.11(3), 484-497, 2016, Online available from: https://sciendo.com/article/10. 1515/mmcks-2016-0011 (accessed 14 November 2019).

[22] Quintino, A.; Lorenco, J. C.; Catalao-Lopez, M. An integrated risk management model for an oil and gas company, 2013, Online available from: https://www.researc hgate.net/publication/260929937_An_integrated_risk_mana gement_model for_an_oil and gas company (accessed 11 November 2020).

[23] The European Chemical Industry Council. Facts and Figures, 2018, Online available from: https://cefic.org/a-pillar-of-the -european-economy/

[24] Official Website «Federal state statistics service». Online available from: https://rosstat.gov.ru/ (accessed 11 November 2020).

[25] Official Website «Russian Business Consulting». Online available from: https://www.rbc.ru/ (accessed 11 November 2020).

[26] Official Website «PJSC «SIBUR Holding». Online available from: http://investors.sibur.com/results-centre/financial-resu lts.aspx?sc lang=ru-RU (accessed 11 November 2020).

[27] Savchina, O.V. The mechanism of stabilization of activity of commercial banks in the Russian Federation during the crisis (on an example of systemically important banks), $\mathrm{PhD}$ thesis, Moscow, RUDN Publishing, 2013. 